\title{
Recurrent laryngeal neuropathy secondary to nerve compression by melanomas - case report
}

[Neuropatia laríngea recorrente secundária à compressão por melanomas - relato de caso]

\author{
J.M. Alonsol, G.S. Rosal, A. Hataka ${ }^{2}$, C.A. Hussni ${ }^{2}$, M.L. Conceição', \\ M.J. Watanabe $^{2}$, C.A. Rodrigues ${ }^{2}$, A.L.G. Alves ${ }^{2 *}$ \\ ${ }^{1}$ Aluno de pós-graduação - Faculdade de Medicina Veterinária e Zootecnia - Universidade \\ Estadual Paulista - Botucatu, SP \\ ${ }^{2}$ Faculdade de Medicina Veterinária e Zootecnia - Universidade Estadual Paulista - Botucatu, SP
}

\begin{abstract}
Recurrent laryngeal neuropathy (RLN) etiology can be acquired, iatrogenic or idiopathic. There are no previous reports of RLN caused by recurrent laryngeal nerve compression by melanomas. This report describes a horse presenting severe dyspnea and progressive weight loss. Physical exam demonstrated tachycardia, tachypnea, inspiratory dyspnea at rest, neck extension and mydriasis. Temporary tracheotomy was performed and videoendoscopic examination diagnosed grade IV laryngeal paralysis. The animal came suddenly to death by suppurative bacterial pneumonia. At necropsy, it was possible to observe multiple melanotic epithelioid melanoma nodules compressing the recurrent laryngeal nerve, alongside with lung and parotid metastasis. This finding emphasizes the importance of establishing a differential diagnosis for tumor mass compression in the etiology of RLN, especially melanomas in gray horses, with or without cutaneous manifestations of masses.
\end{abstract}

Keywords: horse, melanocyte, hemiplegia, larynx

\section{RESUMO}

A neuropatia laríngea recorrente $(N L R)$ pode apresentar etiologia adquirida, iatrogênica ou idiopática. Não há relatos prévios da ocorrência da NLR causada pela compressão do nervo laríngeo recorrente por melanomas. Este relato descreve um equino apresentando dispneia grave e perda de peso progressiva. $O$ exame físico demonstrou taquicardia, taquipneia, dispneia inspiratória em repouso, extensão do pescoço e midríase. Foi realizada traqueotomia temporária e exame videoendoscópico, mediante o qual se diagnosticou paralisia laríngea grau IV. O animal veio a óbito por pneumonia bacteriana supurativa. Na necropsia, foi possível observar múltiplos nódulos de melanoma epitelioide amelanótico comprimindo o nervo laríngeo recorrente, juntamente com metástases pulmonares e parotídeas. Este achado enfatiza a importância de estabelecer um diagnóstico diferencial nos casos de NLR, pensando-se na compressão nervosa por massas tumorais, especialmente melanomas em cavalos tordilhos, com ou sem manifestações cutâneas de massas.

Palavras-chave: cavalos, melanócito, hemiplegia, laringe

\section{INTRODUCTION}

Recurrent laryngeal neuropathy (RLN) is a welldocumented clinical condition in young racehorses (Dixon et al., 2003; Kraus et al., 2003; Brown et al., 2004; Taylor et al., 2006; McCarrel and Woodie, 2015), especially in racing Thoroughbreds, leading to decreased performance (Hackett et al., 1991; Martin et al., 2000; Russel and Slone, 1994; Stick et al., 2001). It is characterized by arytenoid cartilage

Recebido em 27 de novembro de 2017

Aceito em 24 de janeiro de 2019

*Autor para correspondência ( corresponding author)

E-mail: ana.liz@unesp.br paralysis and consequent atrophy of the dorsal and lateral cricoarytenoid muscles.

The etiology of RLN can be acquired/iatrogenic or idiopathic (Dixon et al., 2001; McCarrel and Woodie, 2015). Laryngeal paralysis is also related to any potential damage to the vagosympathetic trunk, especially those affecting the guttural pouches, the neck, and cranial portion of the thorax. These causes include inflammatory reaction after perivascular injections or trauma, guttural pouch mycosis or 
empyema, neoplasia - such as mediastinal lymphosarcomas and thyroid carcinomas - and surgical procedures of the neck (Dixon et al., 2001; Mayhew, 2003; Fulton et al., 2014). To the author's knowledge, there are no previous reports of RLN secondary to recurrent laryngeal nerve compression by melanomas.

\section{CASE REPORT}

An eight year old, male, gray quarter horse gelding was admitted to the Veterinary Hospital with history of dyspnea, progressive increase of respiratory noise and weight loss for two months.

Upon arrival, physical examination revealed intense inspiratory dyspnea without decreased airflow at the nares, tachycardia, tachypnea, cervical extension, mydriasis and widespread mild lung crackles. In order to maintain the airflow without risk of collapse, the horse underwent temporary tracheostomy and posterior endoscopic examination. Endoscopic procedure allowed the identification of grade IV left RLN with severe larynx asymmetry at rest and no substantial movement of the left arytenoid, presenting edematous appearance. After presenting all the treatment options to the owner, permanent tracheostomy was chosen in order to restore the airway patency and to reduce treatment costs (Chesen and Rakestraw, 2008), as the animal could not be used for sports anymore.

Since the horse was presenting marked cachexia (body score II/V), it was suggested that the nutritional condition of the patient be improved prior to the surgical procedure. However, even after receiving $150 \%$ of its daily energy requirements of $18 \%$ protein feed plus oil per day (total of $49.95 \mathrm{Mcal} / \mathrm{kg} /$ day) for two weeks, it was not possible to observe any improvement in its body condition. Throughout this period significant worsening in pulmonary auscultation was observed. The hemogram revealed severe leucopenia, leading to the diagnosis of septic pneumonia. The patient suddenly came to death less than two days after the diagnosis.

At necropsy, there were multiple black nodules compressing the RL nerve (Figure 1A / 1B) and the parotid region (Figure 1C). The lungs exhibited hemorrhagic and edematous appearance with multifocal areas of neutrophilic inflammatory infiltrate and bacterial colonies, characterizing a suppurative bacterial pneumonia. Intense edema of the left arytenoid (Figure 1D) and metastasis in the left lung lobe were also observed. Neither cutaneous masses nor additional metastasis were identified.

Tumor samples were collected for histopathology, demonstrating an intense proliferation of neoplastic cells mixed with fibrous stroma beams. The cells had predominantly oval, but indistinct, cytoplasm filled with copious amounts of brown pigment. Nuclei were large and basophilic, with prominent nucleoli, moderate anisocytosis, anisocariosis and pleomorphism, outlining a melanotic epithelioid melanoma. Better visualization and count of atypical mitosis were impaired by the intense amount of pigmentation of the neoplastic cells.

\section{DISCUSSION}

Melanoma is a common neoplasia that affects gray horses older than 5 years, without gender predisposition (Philips et al., 2015; Knowles et al., 2016). The age presented by the related horse falls among the described range for occurrence of melanoma, but does not fit the common age range for the occurrence of malignant melanomas (Valentine, 1995; Philips and Lembcke., 2013).

The absence of apparent tumor masses in the insertion of the tail, perineum and anus also contradicts the main manifestation of melanomas in horses, since cutaneous form is the most commonly seen, being present in nearly $80 \%$ of all gray horses older than 13 years (Valentine, 1995; Smith et al., 2002; Moore et al., 2013; Philips and Lembcke., 2013). The absence of cutaneous manifestation of melanomas in horses is rare, but some cases of gastrointestinal tract, guttural pouch, musculoskeletal system and salivary glands occurrence were previously described (Traver et al., 1977; Milne, 1986; Baptiste et al., 1996; Jones et al., 1997; MacGillivray et al., 2002; Caston and FalesWillians, 2010; Philips and Lembcke., 2013). 


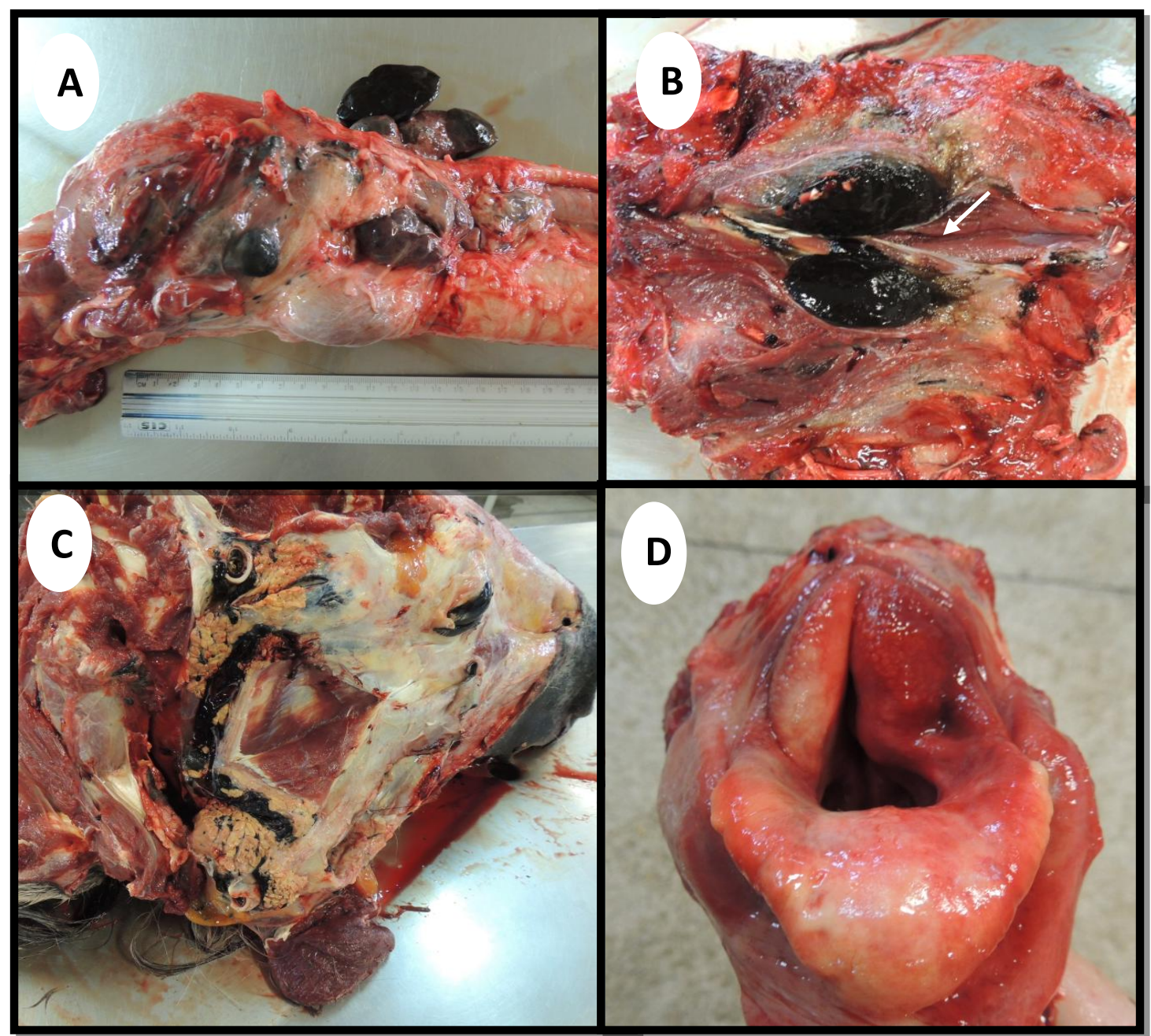

Figure 1. Post mortem findings of a horse presenting multiple melanoma nodules. A- Presence of multiple blackened nodules in the larynx region; B- Recurrent laryngeal nerve (arrow) compressed by a melanoma.; C- Lateral view of the head after the removal of skin and superficial muscles, showing the presence of several blackish masses in the parotid region; D- Left arytenoid cartilage presenting asymmetry and edema.

Melanomas usually have benign features in horses. Data on the occurrence of malignancy can vary from a rate of $14 \%$ for MacGillivray et al. (2002) to 66\% (Gorham and Robl, 1986) and even the absence of malignancy evidence, showed by Seltenhammer et al. (2003) in a group of 296 gray horses who had 50\% of dermal melanoma occurrence. However, without treatment, the major part of tumors can progress to malignant behavior through invasion by either vascular or lymphatic metastasis (Philips and Lembcke., 2013).

Clinical signs of RLN can vary according to its degree. Inspiratory noise at rest or exercise, poor performance and exercise intolerance can be present (Martin et al., 2000; McCarrel and Woodie, 2015). In the reported case, it was possible to observe inspiratory dyspnea at rest due to the severe degree of RLN (Rakesh et al., 2008). The diagnosis was made associating clinical signs and videoendoscopic findings.

RLN was observed in the left arytenoid, corroborating the previous descriptions of major left side incidence (95\%). The anamnesis did not elucidate any etiologic factor, as occurrence of guttural pouch disease, perineural injections in the cervical region, lymphadenopathy and/or trauma (Dixon et al., 2001; McCarrel and 
Woodie, 2015), initially suggesting an idiopathic characterization.

Anatomically, the RL nerve is clustered to the vagus nerve as it leaves the nucleus ambiguus, in the brainstem. Extracranially, the vagus nerve descends in caudal the direction within the carotid sheath, between the internal carotid arteries and the adjacent jugular vein. The left RL nerve leaves the vagus nerve at the level of the aortic arch, then passes through the aorticopulmonary window and ascends vertically through the superior mediastinum to reach the tracheoesophageal groove. The RL nerve enters the larynx caudal to the cricoarytenoid joints and innervates the intrinsic laryngeal muscles (Paquette et al., 2012). In the present case, multiple melanomas were compressing the RL nerve at the tracheoesophageal groove and cricoarytenoid joints.

In humans, previous reports described the occurrence of RL nerve compression by tumors such as bronchogenic carcinoma, thyroid, thymus and esophagus cancer, paragangliomas and schwannomas (Paquette et al., 2012; Patel et al., 2013). Dixon et al. (2001) pointed thyroid carcinomas and mediastinal lymphosarcomas as causes of RL nerve compression in horses. However, to the authors' knowledge, there are no previous reports of RL nerve compression by melanomas.

The treatment of RLN consists in restoring glottic rhyme diameter and preventing dynamic collapse during inspiration. Despite all the laringoplasty techniques described, their results are still inconsistent (Ahem and Parente, 2008). The progressive weight loss observed was initially attributed to severe dyspnea and decreased food intake. However, even after airflow restoration and adequate nutritional support, the animal did not demonstrate body score improvement. The tumor itself could have caused weight loss, as described by Moore et al. (2013). Moreover, the dyspnea could also have led to aspirative pneumonia with bacterial colonization and consequent suppurative bacterial pneumonia. These two events were pointed as pivotal factors for the development of the pneumonia in this case.

The World Health Organization (WHO) classifies the epithelial and melanocytic skin tumors of domestic animals as melanocytoma (benign melanoma), melanoacanthoma, malignant melanoma and melanocytic hyperplasia (lentigo) (Goldschmidt et al., 1998). Melanocytic tumors are also named according to cell morphology. This way, epithelioid tumors contain round cells, with discrete cell borders, abundant clear cytoplasm, large nuclei and prominent nucleoli. Spindle cell tumors are arranged in streams and interweaving bundles, similar to fibrosarcomas, but the nuclei tend to be larger with nucleoli more prominent. The mixed type is characterized by the overlap of both patterns. Finally, the whorled or dendritic form with spindle-shaped cells organized in a fingerprint pattern is described as occurring only in the skin (Smith et al., 2002; Philips and Lembcke., 2013). Although the histological type of melanoma and the presence of metastasis observed were similar to other reports (Baptiste et al., 1996; Smith et al., 2002; Philips and Lembcke., 2013), the unusual presentation and distribution of melanomas and its clinical consequences are what make this case scientifically relevant.

\section{CONCLUSION}

Alongside all conventional etiologies for RLN occurrence, this report also places melanomas as a potential RLN cause that may trigger serious complications which, according to severity, can even lead to death. In cases of RLN, special attention is needed due to the possibility of atypical location, absence of cutaneous manifestation and even malignant behavior of melanomas, whether inside or outside the usual range of age for its occurrence. Thereby, the importance of a thorough exploration among all etiological hypotheses for RLN becomes evident and also may represent the difference between a successful and a bad outcome for these animals.

\section{REFERENCES}

AHERN, B.J.; PARENTE, E.J. Surgical complications of the equine upper respiratory tract. Vet. Clin. N. Am. Equine Prac., v.24, p.465-484, 2008.

BAPTISTE, K.; MOLL, H.D.; ROBERTSON, J.L. Three cases of tumors associated with the equine guttural pouch. Can. Vet. J., v.37, p.499$501,1996$. 
BROWN, J.A.; DERKSEN, F.J.; STICK, J.A.; HARTMANN, W.M. et al. Effect of laryngoplasty on respiratory noise reduction in racehorses with laryngeal hemiplegia. Equine Vet. J., v.36, p.420-425, 2004.

CASTON, S.S.; FALES-WILLIAMS, A. Primary malignant melanoma in the oesophagus of a foal. Equine Vet. Educ., v.22, p.387-390, 2010 .

CHESEN, A.B.; RAKESTRAW, P.C. Indications for and short- and long-term outcome of permanent tracheostomy performed in standing horses: 82 cases (1995-2005). J Am Vet Med Assoc, v.232, n. 9, p.1352-1356, 2008.

DIXON, P.M.; MCGORUM, B.C.; RAILTON, D.I.; HAWE, C. et al. Laryngeal paralysis: a study of 375 cases in a mixed-breed population of horses. Equine Vet. J., v.33, p.452-458, 2001.

DIXON, P.M.; McGORUM, B.C.; RAILTON, D.I.; HAWE, C.; TREMAINE, W.H.; DACRE, K.; McCANN, J. Long-term survey of laryngoplasty and ventriculocordectomy in an older, mixed-breed population of 200 horses. Part 1: Maintenance of surgical arytenoid abduction and complications of surgery. Equine Vet. J., v.35, issue 4, p.389-396, 2003.

FULTON, I.C.; ANDERSON, B.H.; STICK, J.A.; ROBERTSON, J.T. Larynx. In: AUER, J.A., STICK J.A. Equine surgery. 4.ed. Philadelphia: Saunders, 2012, p.592-622.

GOLDSCHMIDT, M.H.; DUNSTAN, R.W.; STANNARD, A.A.; VON TSCHARNER, C. et al. Histological classification of epithelial and melanocytic tumors of the skin of domestic animals. Washington: World Health Organization, 1998.

GORHAM, S.; ROBL, M. Melanoma in the grey horse: the darker side of equine ageing. Vet Med., v.81, p.446-448, 1986.

HACKETT, R.P.; DUCHARME, N.G.; FUBINI, S.L.; ERB, H.N. The reliability of endoscopic examination in assessment of arytenoid cartilage movement in racehorses. Part 1: subjective and objective laryngeal evaluation. Vet Surg., v.20, p.180-184, 1991.

JONES, T.C.; HUNT, R.D.; KING, N.W. Veterinary pathology. 6.ed. Philadelphia: Williams \& Wilkins, 1997. 858p.
KNOWLES, E.J.; TREMAINE, W.H.; PEARSON, G.R.; MAIR, T.S. A database survey of equine tumors in the United Kingdom. Equine Vet. J., v.48, p.280-284, 2016.

KRAUS, B.M.; PARENTE, E.J.; TULLENERS, E.P. Laryngoplasty with ventriculectomy or ventriculocordectomy in $104 \mathrm{draft}$ racehorses (1992-2000). Vet. Surg., v.32, p.530-538, 2003.

MACGILLIVRAY, K.C.; SWEENEY, R.W.; DEL PIERO, F. Metastatic melanoma in horses. J. Vet. Int. Med., v.16, p.452-456, 2002.

MARTIN, B.B.; REEF, V.B.; PARENTE, E.J.; SAGE, A.D. Causes of poor performance of horses during training, racing, or showing: 348 cases (1992-1996). J. Am. Vet. Med. Assoc., v.216, p.554-558, 2000.

MAYHEW, I.G. Neurology of recurrent laryngeal neuropathy and the thoraco-laryngeal reflex. In: DIXON, P.; ROBINSON, E.; WADE, J.F. WORKSHOP ON EQUINE RECURRENT LARYNGEAL NEUROPATHY, 2003, Stratford-upon-Avon. Proceedings... Stratfordupon-Avon: [s.n.], 2003. p.5-8.

MCCARREL, T.M.; WOODIE, J.B. Update on laryngeal disorders and treatment. Vet. Clin. N. Am. Equine Prac., v.31, p.13-26, 2015.

MILNE, J.C. Malignant melanomas causing Horner's syndrome in a horse. Equine Vet. J., v.18, p.74-75, 1986.

MOORE, J.S.; SHAW, C.; SHAW, E.; BUECHNER-MAXWELL, V. et al. Melanoma in horses: current perspectives. Equine Vet. Educ., v.25, p.144-151, 2013.

PAQUETTE, C.M.; MANOS, D.C.; PSOOY, B.J. Unilateral Vocal Cord Paralysis: A Review of CT Findings, Mediastinal Causes, and the Course of the Recurrent Laryngeal Nerves. RadioGraphics, v.32, p.721-740, 2012.

PATEL, A.S.; CARTER, J.M.; FRIEDLANDER, P.L.; KANDIL, E. Brachial plexus compression: a rare sequelae of malignant papillary thyroid carcinoma. Int. J. Clin. Exp. Med., v.6, p.606-608, 2013.

PHILIPS, J. Melanoma. In: SPRAYBERRY, K.; ROBINSON, N. Current therapy in equine medicine. 7.ed. St Louis, Missouri: Elsevier Saunders, 2015. p.524-527. 
PHILIPS, J.C.; LEMBCKE, L.M. Equine melanocytic tumors. Vet. Clin. Equine Pract., v.29, p.673-687, 2013.

RAKESH, V.; DUCHARME, N.G.; CHEETHAM, J.; DATTA, A.K. et al. Implications of different degrees of arytenoid cartilage abduction on equine upper airway characteristics. Equine Vet. J., v.40, p.629-635, 2008.

RAKESTRAW, P.C. Indications for and shortand long-term outcome of permanent tracheostomy performed in standing horses: 82 cases (1995-2005). J. Am. Vet. Med. Assoc., v.232, p.1352-1356, 2008.

RUSSEL, A.P.; SLONE, D.E. Performance analysis after prosthetic laryngoplasty and bilateral ventriculectomy for laryngeal hemiplegia in horses: 70 cases (1986-1991). $J$. Am. Vet. Med. Assoc., v.204, p.1235-1241, 1994.

SELTENHAMMER, M.H.; SIMHOFER, H.; SCHERZER, S.; ZECHNER, P. et al. Equine melanoma in a population of 296 grey Lippizaner horses. Equine Vet. J., v.35, p.153$157,2003$.
SMITH, S.H.; GOLDSCHMIDT, M.H.; MCMANUS, P.M. Review article a comparative review of melanocytic neoplasms. Vet. Pathol., v.39, p.651-678, 2002.

STICK, J.A.; PELOSO, J.G.; MOREHEAD, J.P.; LLOYD, J. et al. Endoscopic assessment of airway function as a predictor of racing performance in Thoroughbred yearlings: 427 cases (1997-2000). J. Am. Vet. Med. Assoc., v.7, p.962-967, 2001.

TAYLOR, S.E.; BARAKZAI, S.Z.; DIXON, P. Ventriculocordectomy as the sole treatment for recurrent laryngeal neuropathy: long-term results from ninety-two horses. Vet. Surg., v.35, p.653657, 2006.

TRAVER, D.S.; MOORE, J.N.; THORNBURG, L.P.; JOHNSON, J.H. et al. Epidural melanoma causing posterior paresis in a horse. J. Am. Vet. Med. Assoc., v.170, p.1400-1403, 1977.

VALENTINE, B.A. Equine melanotic tumors: a retrospective study of 53 horses (1988-1991). J. Vet. Int. Med., v.9, p.291-297, 1995. 